\title{
Summary
}

In order to obtain 3,13,19-trimethyltricosanoic acid, which is assumed to be the structure of phthioic acid, by the Kolbe's electrolytic condensation of 6-methyldecanoic acid and ethyl hydrogen 2,12-dimethyltridecane-1,13-dicarboxylate 11,15-dimethylpalmitic acid was prepared by the Kolbe's electrolytic condensation of dihydrorhodinic acid and ethyl hydrogen sebacate, as a model experiment of electrolytic reaction, with an yield of $31 \%$. In this reaction, 2,6,9,13-tetramethyltetradecane and hexadecane -1 , 16-dicarboxylic acid were recognized to be byproducts.

(Received March 31, 1950)

36. 謭江辰男 : 結核菌江含まるる枝䥊脂肪酸類の合成研究 (第 11 報 $)^{1)}$ フチォン酸関する研究 (IX) 6-メチルデカン酸と 2,12-ヂメチルトリデカ

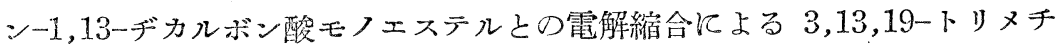
ルトリコサン酸合成に於ける副生成物について (5,14-デメチルオクタデカ ン及び $2,12,15,25$-テララチルへキサュサン-1,26-ヂカルボン酸の確認)

Tatsuo Moroe: Synthesis of Branched-Chain Fatty Acids Present in Tubercle Bacilli.XI. Studies of Phthioic Acid. (9). Identification of 5,14-Dimethyloctadecane and 2,12,15,25-Tetramethylhexacosane-1, 26-dicarboxylic Acid-Byproducts in the Synthesis of 3,13,19-Trimethyltricosanoic Acid by Electrolysis of 6-Methyldecoic Acid and Monoester of 2,12-Dimethyltridecane-1,13-dicarboxylic Acid.

(Chemistry Department, Institute for Infectious Diseases, University of Tokyo)

前報 (第10報) に) に於て著者は 3,13,19-トリメチルトリコサン酸（フチオン酸の Polgar-Robinson 式）夌合

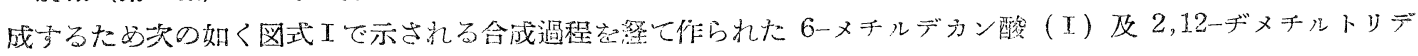

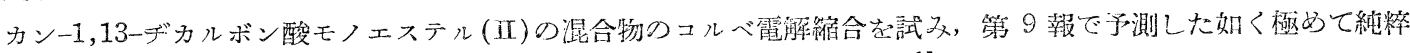

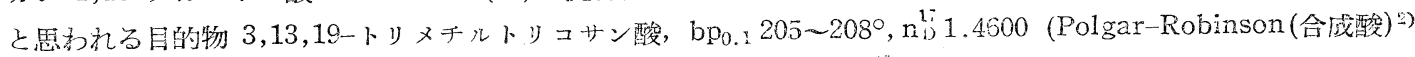
$\mathrm{bp}_{0.1} 208^{\circ} \mathrm{n}_{\mathrm{D}}^{17} 1.4620$; Spielman-Anderson (天然酸) ${ }^{3)} \mathrm{mp} \mathrm{20^{ \circ }}, \mathrm{n} \mathrm{n} 1.4628,[\alpha] \mathrm{D}+12.5^{\circ}$ ), amide mp 43〜

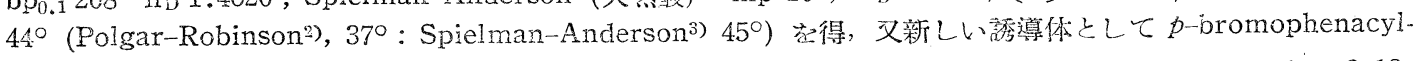
ester mp 97 980 の結晶化に成功したこと定報告したがその最後の合成過程である6ーメチルデカン酸と 2,12-

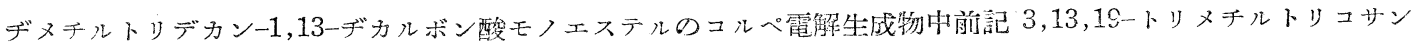

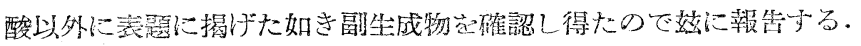

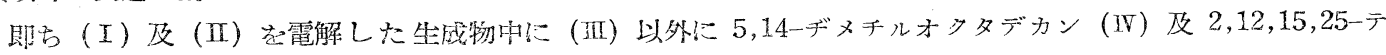

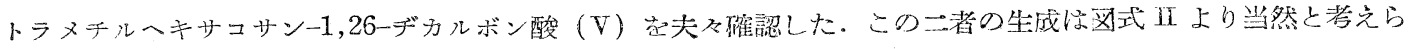
れるぶ (V) の如き C-32 の多枝鎻高級二塩基性酸は交献上余り類列艺見ず，先に合成されたペルヒドロノルビ

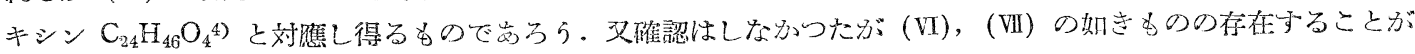

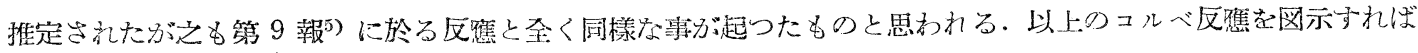
図式 II の如くで岁る。

1) 第10報: Studies of Phthioic Acid, UIl. A New Synthesis of 3,13,19-Trimethyltricosanoic Acid. 本誌 $70,416(1950)$.

2) Polgar, Robinson : J. Chem. Soc. 1945, 389.

3) Spielman, Anderson : J. Biol. Chem. 112, 759 (1936). 
Fig. I ・ 3,13,19ートリメチルトリコサン酸-(Polgar-Robinson のフチオン酸式) 合成径路



(III)

Fig. III. 6-メチルデカン酸と 2,12-デメチルトリデカン-1,13-ディルボン酸モノェステルとの霓解

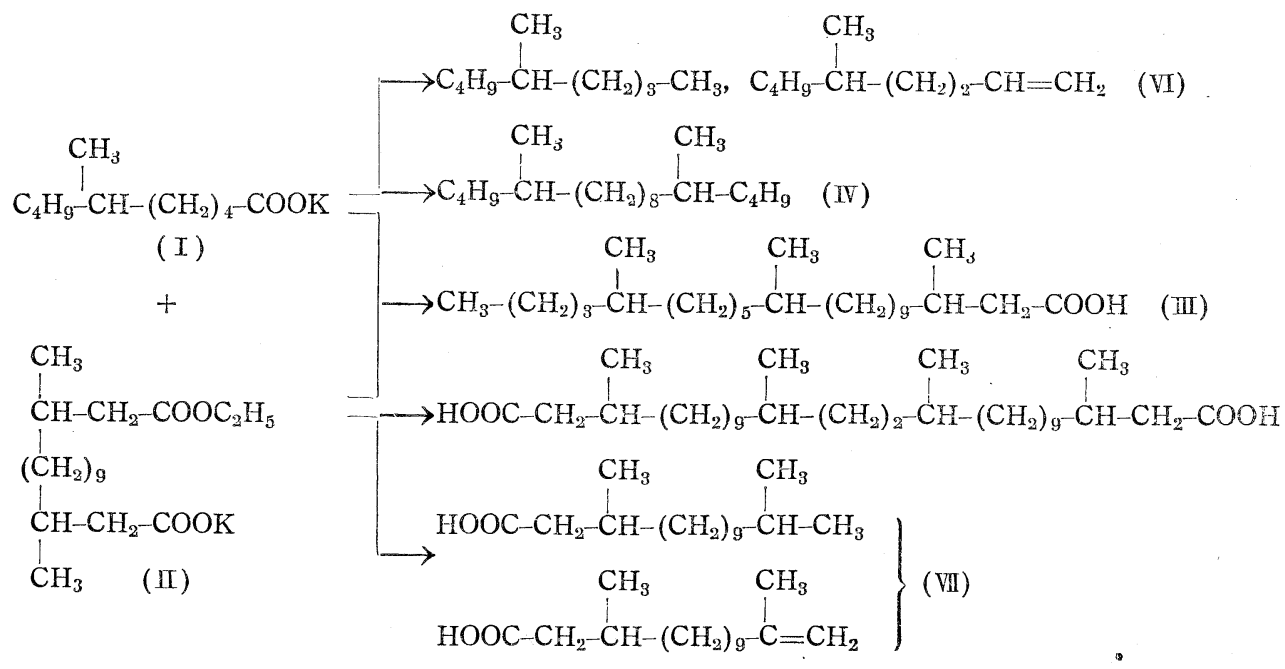




\section{実 驗 $\odot$ 部}



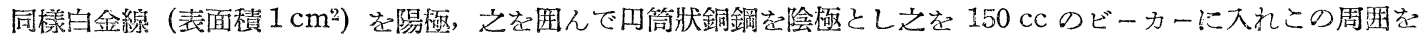
氷水で冷却する.電流密度は摺動抵抗器で調節した。電解液は前記デカルボン酸モノェステル (II) $3.3 \mathrm{~g}$ (1モ ル),6-メチルデカン酸 ( I ) $2.8 \mathrm{~g}$ (1.5 モル), 炭酸加里 $1.9 \mathrm{~g}$ (1.5モル) 这蒸溜水及無水了ルュール各 $20 \mathrm{cc}$ の混合物に溶解し溶液の $\mathrm{pH}$ を（I）で加瀻し 6.8 ～7.0 とする. 電解液の溫度ば $30^{\circ}$ 附近を保ち適時覺找し

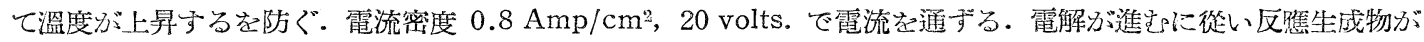
浮上するので之をピペットで探取しつつ別にモノェステル (II) $7.1 \mathrm{~g}, 6$-メチルデカン酸 (I) $8.5 \mathrm{~g}$ の混合物

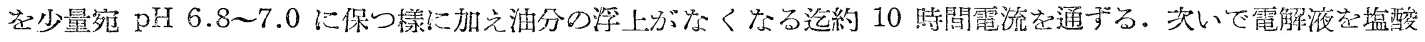
でゅ性となし溜玨で酒精を回收し, 戞留分を炭酸ソーダで弱アルカリ性としェーテルで中性物質を抽出する. 先 に反隹中探取した電解生成物と合すれば中性生成物は $12 \mathrm{~g}$ 得られた。電解液より回收した末反雄形夋の混合物は $2.5 \mathrm{~g}$ で岕る。

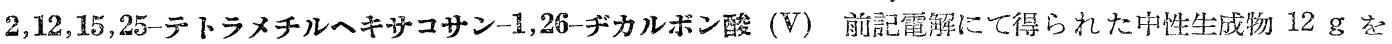


狀液体に水 $200 \mathrm{cc}$ を加える. 上層に浮ぶ若干の油層 (A) を分液しアルカリ液（著しく白濁し暫時加溫すれば 透明となる）をェーテル，石油ェーテル $(1: 1)$ の混合物 $200 \mathrm{cc}$ で液体逨続抽出起行いアルカリ液上り中性物

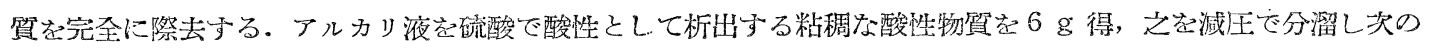
3 溜分, (1) $\mathrm{bp}_{0.1} \sim 195^{\circ} 0.5 \mathrm{~g}$, (2) $\mathrm{bp}_{0.1} \sim 195 \sim 213^{\circ} 2.5 \mathrm{~g}$, (3) $\mathrm{bp}_{0.1} 213^{\circ} 2.0 \mathrm{~g}$ 起得, (2) 空再溜し (4)

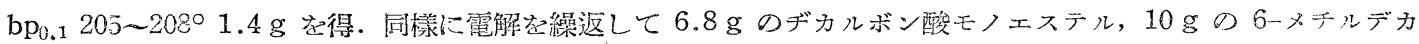

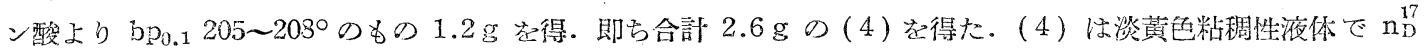

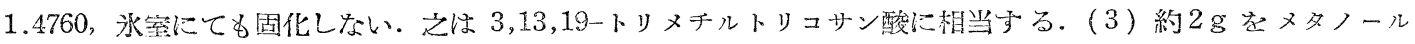




75.58 , H 12.28 .

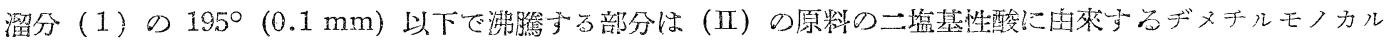
ボン酸 $\left(\mathrm{C}_{16}\right)$ の混合物と思われる。

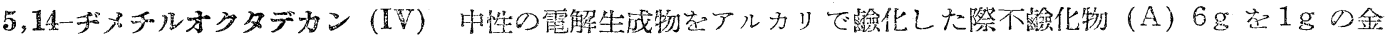

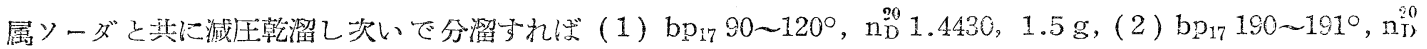

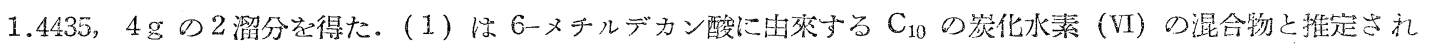
る.（2）は枝顉アイコサンに相当する。 $\mathrm{C}_{20} \mathrm{H}_{42}$ 計算值 C $85.10, \mathrm{H} 14.90$, 実驗值 C 85.23, H 14.51 .

(東景大学傳染扁研究所化学部)

\section{Summary}

In order to obtain 3,13,19-trimethyltricosanoic acid, which was the Polgar-Robinson formula of phthionic acid, 6-methyldecoic acid and 2,12-dimethyltridecane-1, 13-dicarboxylic acid monoethyl ester, were synthesized and the objective compound was obtained by the Kolbe's electrolysis of these two compounds. 5,14-Dimethyloctadecane and $2,12,15,25$-tetramethylhexacosane 26-dicarboxylic acid were identified as the byproducts of this electrolysis.

(Received March 31, 1950) 